\title{
Miranda
}

Revue pluridisciplinaire du monde anglophone /

Multidisciplinary peer-reviewed journal on the English-

speaking world

$14 \mid 2017$

Early American Surrealisms, 1920-1940 / Parable Art

\section{CMAS Latina/o Media Makers}

Presented by the Center for Mexican American Studies, in collaboration with Radio-Television-Film, The University of Texas at Austin, Spring 2017

\section{David Roche}

\section{CpenEdition}

\section{Journals}

Electronic version

URL: http://journals.openedition.org/miranda/10299

DOI: $10.4000 /$ miranda.10299

ISSN: 2108-6559

\section{Publisher}

Université Toulouse - Jean Jaurès

Electronic reference

David Roche, "CMAS Latina/o Media Makers", Miranda [Online], 14 | 2017, Online since 19 April 2017, connection on 16 February 2021. URL: http://journals.openedition.org/miranda/10299 ; DOl: https:// doi.org/10.4000/miranda.10299

This text was automatically generated on 16 February 2021.

\section{$\Theta \Theta \Theta \Theta$}

Miranda is licensed under a Creative Commons Attribution-NonCommercial-NoDerivatives 4.0 International License. 


\section{CMAS Latina/o Media Makers}

Presented by the Center for Mexican American Studies, in collaboration with Radio-Television-Film, The University of Texas at Austin, Spring 2017

\section{David Roche}

1 The three screening events were held at UTA on February 28 (Rose Troche), March 7 (Jesús Salvador Treviño) and April 11, 2017 (Jim Mendiola) and were organized by Mary Beltrán ${ }^{1}$ and Charles Ramírez Berg, ${ }^{2}$ sponsored by CMAS in conjunction with RTF.

\section{Rose Troche ${ }^{3}$}

2 Mary Beltrán thanked Rose Troche for being here and summed up her career. Her background as a first generation Puerto Rican American is vital to her work. Her trajectory took her from showcasing independent filmmaking with Go Fish (USA, 1994), to receiving the Critics Award and an Acting Prize for Patricia Clarkson ${ }^{4}$ at the American Film Festival in Deauville for The Safety of Objects (UK/USA/Canada, 2001), to acting as director, screenwriter and executive producer on The L Word (Showtime, 2004-2009). She has recently turned her attention to the web and has been experimenting with virtual technology since 2014. She received a Time-Warner fellowship for a LGBTQ\&A show. She is currently working on two feature films.

Rose Troche is a gifted speaker, one who can easily make an audience laugh and whose frankness about personal issues such as her identity or the death of a loved one is touching. Born in 1964, Troche studied at the University of Illinois. She fondly remembers her film teachers (Peter Hayles, Linda Williams) there; they were still studying Laura Mulvey, so the focus was on disrupting cinema, not doing narrative. Troche was staunch in her determination to make experimental art and loved to repurpose material found on campus. She took her Super-8 camera everywhere and shot out windows (she does the same today with her digital camera). Her first movie, a series of short films entitled Gabriella (1991-1993), made money, but never for Troche and fellow screenwriter Guinevere Turner. ${ }^{5}$ It was largely made with found footage, and 
shot before Go Fish, but edited after promoting the feature film. Troche's early work was, she admitted, influenced by her friend, artist Tom Quirk. ${ }^{6}$

When Troche came out as a lesbian, she was very much involved in her community, comprised mainly of black men and white lesbians who had been activists before in Chicago. With Go Fish, she wanted to make a piece that was diverse, even if the film has a majority of white women. It was a film by, for and about women, one that would show at LGBTQ festivals. The movie was shot with friends in their apartments; they wanted to show how they were to each other's families. Troche wanted to open the movie with a hate crime, but Guinevere convinced her not to, arguing it would make the movie too narrative. A lot of this film came back in The $L$ Word, but dressed in a different package. She was still in film school when she made it and never imagined the film, produced for $\$ 125,000$, would be so successful. It was shot on $16 \mathrm{~mm}$ with a clunky war camera. Troche recut the movie after Sundance when she sold it to a distributor. It made about $\$ 4.5$ million. Troche remembered how strange it was to travel first class while promoting the film and coming home not being able to pay the rent. The film is now tied up with Warner Bros., so she makes very little off of it; Troche told the audience it was important not to be naïve selling the rights of your work.

Troche then moved to London, where she directed Bedrooms and Hallways (UK, 1998), a movie she started adapting with its author, Robert Farrar, before it had even been greenlit by the publisher. It was a very different experience: she had resources, an actual crew, got paid, and it was the first time she worked with real actors, notably Kevin McKidd who would later star in Rome (HBO/BBC, 2005-2007). The film marked a moment in Troche's life when she didn't know who she wanted to be and didn't want to be labeled. It raises the question: if I sleep with a man, does that make me not a lesbian? Troche insisted on how demarcating is the moment when you come out, and cited Kristen Stewart's coming out on Saturday Night Live as a poignant example. ${ }^{7}$ Troche's experience was that people always identified her as lesbian (except for her accountant!), but seldom realized she was Puerto Rican.

6 Her third feature film, The Safety of Objects, was another adaptation, based on a collection of short stories by A.M. Homes. It was flattering because this time someone had come to her to ask her to direct, though they still saw her as the director of Go Fish, Bedrooms and Hallways having not registered in the U.S. She was given a chance to work with a real budget ( $\$ 8$ million), famous actors (Glenn Close, ${ }^{8}$ who loved the script) and a bigger crew. Troche had decided to stop looking into her own life and went full throttle with the film adaptation. This was a problematic moment in her life because she finally owned things after sleeping on the floor until she was thirty-five. It was a heartbreak, however, because the movie didn't break even and only made \$3 million worldwide. Troche said, as a woman director, it is much more difficult to fail and come back. But she is very proud of The Safety of Objects and thinks that you can tell that, in spite of its white upper class material, it was written from the perspective of someone who's not white, that there's a sense of disconnect in the adaptation.

7 After this movie, Troche looked back on her life and thought: I've made experimental shorts, a DIY movie, a foreign film, a feature film. She wanted to practice her craft more and wanted to move more quickly on her feet. That meant doing television, but she wanted to do hour-long television, which meant going to HBO. The "gay mafia," she joked, helped her get a job on Six Feet Under (HBO, 2001-2005), a show that was already 
en cours and which she loved. She shot Episode 2.3, entitled "The Plan." "Television is a well-oiled machine," Troche said, "It works with you or without you."

She was then offered to direct a pilot for a show called The Ranch or The Star, but she was worried she was going to be pigeonholed as a gay director. Finally, she decided to do the gay show after all and started working on The $L$ Word, directing twelve episodes and writing five. Showtime had already done Queer as Folk (2000-2005) and Soul Food (2000-2004) at the time, and the producers were passionate. The series reminded her of Go Fish: what would it be like to be working on these themes with money this time? Pam Grier had agreed to star in the show, initially as an old school lesbian, but The L Word team (including Troche, who directed the pilot) was not buying her as a lesbian; her character then became the sister of mixed-race Bette Porter (Jennifer Beals). Working on the series was a special moment. They were fully aware it was soap opera, but they also knew that people all over the country would watch it and feel visible. So they really felt they were doing something for the better. It wasn't just about lesbian visibility; the series depicts a world where women are empowered. The L Word was an event. People watched it in lesbian bars. It had a lot of sex scenes, and Troche directed many of them, even though prior to working on the Showtime series she felt uncomfortable doing so. Troche remembered one time in particular when Jennifer Beals asked her if she wanted her to have an orgasm. Troche loved working with Jennifer: they were the same age, were both women of color, and both from Chicago. Troche did three seasons of The L Word, but quit when she felt that she was not being used properly. She resigned for season 4, but returned for season 5 to direct an episode where everybody had sex, and for the "sad" season 6. One of the reasons she left was that none of the Latina characters were played by Latina actresses-Sarah Shahi, for instance, is Spanish-Lebanese. Troche regrets not having put her foot down. Troche is glad that there's more brave casting today and that there's a growing trend of women comedians.

9 Troche did a lot of directing for hire after that: the pilot of South of Nowhere (Nickelodeon, 2005-2008), and two episodes of Law \& Order (NBC, 1990-2010). "Directing for hire is the pits, she said, "It's good pay, but it's not your show." Now that she had money, though, Troche figured she had the freedom to make more daring decisions. She could use TV to make money and do the things she loved. She was interested in making web series. She did three episodes of Blue (WIGSCO, 2012-2014), then executive produced Hunting Season (Logo, 2012-2015). In 2009, she made a short film for the new museum in Chinatown, with the highly talented cinematographer Bradford Young, recently nominated for an Oscar for Arrival (USA, Denis Villeneuve, 2016). She wrote a story about parents coming to the U.S. and how the values of your country estrange you from those of your parents' land. In 2014, curious about the immersive potential of VR $360^{\circ}$, she participated in the Perspective Series, directing "Chapter 1: The Party." It was presented at Sundance in 2015 as an installation. It allowed you to experience a sexual assault at a college party from the points of view of the female victim and the male assailant. The following year, Troche directed "Chapter 2: The Misdemeanor." This time, the focus was on a police shooting, from the perspective of two young men and two police officers. "The sad part," Trobe explained, "is that audiences usually only experienced one perspective," and she has since wondered if it was difficult for audiences to relate to a police officer. 

Latino crew. Troche wanted to explore how she would represent her own people, and noticed similarities with Go Fish, especially her interest in mother-daughter relationships. Troche clearly sees writing and directing as therapeutic in this respect. Troche has also been working on a series entitled LGBTQ\&A.

During Q\&A, Troche responded to questions concerning artistic creation in the Trump era and her optimism concerning the entertainment industry today. Troche said she was happy she had released If Not Love (USA/Australia) in 2017. She would like to work with more people of color. She admitted that you promise yourself lots of things when you start making a TV show, but that in the end, the body count has to be high when people of color are involved; The Wire (HBO, 2002-2008) is a case in point. Troche has realized from teaching at a Latino school in Chicago that the gang situation has only gotten worse. Troche believes that things have gotten better for Latino artists, thanks to digital platforms, the increase in the number of women performers, but she concluded that the majority of people making money, including in VR, are still white men.

\section{Jesús Salvador Treviño9}

Charles Ramírez Berg presented today's director. Born in El Paso in 1946, Treviño grew up in Southern California. As a student, he documented the Mexican American Civil Rights movement in the 1960s. He has since had an amazing career, working with the most influential theater troupes. And he had a second career directing prime time TV shows, including NYPD Blue (Fox, 1993-2005), Babylon 5 (PTEN, 1994-1998), E.R. (NBC, 1994-2009), Third Watch (NBC, 1999-2005), Law \& Order (NBC, 2001-2011), Prison Break (Fox, 2005-2009). He also co-produced the series Resurection Blvd. (Showtime, 2000-2002), which won The Alamo award. He is now a member of the Directors Guild Award.

Treviño proposed to focus on storytelling both as a filmmaker, an author and a radio show producer. He sees himself above all as a storyteller regardless of the medium and thinks that potentially everyone in the room is a storyteller. The important question has to do with the kind of stories we want to tell and which medium we are going to use for a given story.

14 Treviño screened a fifteen-minute compilation of some of his work, made by the Director's Guild as a tribute to his career. It included clips from his documentary Yo soy chicano (Mexico/USA, 1972), his feature film Raíces de sangre (Mexico/USA, 1978) and American Playhouse: Seguin (PBS, 1982), which presents a Mexican American view of the battle of the Alamo. The compilation also included excerpts from episode 1.17 of NYPD Blue "Black Men Can't Jump," New York Undercover (Fox, 1994-1999), Third Watch, and the pilot of Resurection Blvd., a series which focuses on a struggling Latino family.

For Treviño, every story has a beginning, a middle and an end. In 1972, it was a challenge making Yo soy chicano. There were no Chicano Studies departments, and El Paso and Northridge had just started such courses. So there was no sense as to who Mexican Americans were as a people. Treviño wanted to make a film about events going on at the time, so as to understand where his community came from: "Part of the story had to be our history." The problem was: there were very little visuals about 
Mexican American history, apart from a few documents from the late 19th century and some from the 1930s-1960s. So the challenge was telling a story without the visuals. Treviño's solution was to make his own. Constraints can sometimes stimulate invention. He used actors in still images, for instance, of Mexican social reform activist Ricardo Flores Magón in prison writing about the unsuccessful invasion of Baja California.

His interest in Seguin, starring Edward James Olmos among others, had to do with the fact that most Americans knew The Alamo through John Wayne's 1960 film. Few people knew that Mexican Americans also fought at the Alamo. The movie was based on the memoirs of Seguin, who was sent to get recruitments but unfortunately returned too late, so it ended up being his job to bury the dead. The PBS production also aimed at debunking the myth that the soldiers had all died heroically, when many had, in fact, been executed. The film also reminded audiences that the Mexican Americans had been the ones to invite the Americans to settle in Texas in the 1820s. For this story, Treviño, who also wrote the script, opted for a flashback structure. Indeed, one of the important aspects of storytelling is deciding on the angle you are going to take so your story rings of truth.

17 As a science fiction nerd, he was very happy to get a chance to work on Star Trek: Voyager (CBS, 1995-2001). His first episode, 3.13 ("Fair Trade"), required a huge set that would feature 22 distinct alien races. Disappointed by the limited set the stage designers had built, he looked for a solution to create the illusion of a bigger space. He decided to resort to blue screen, having done so before while shooting SeaQuest 2032 (NBC, 1993-1996). They used three blue screens to create a portal that would double the size of room. The producer backed him up, telling the stage designers that the director was in charge. So again, constraints can lead to interesting choices.

Treviño ended his talk by screening an excerpt from his more recent work, Visions of Aztlán (2010), a documentary about Chicano artists, featuring interviews in which they speak of how they reacted to the Civil Rights movement. The question asked in the clip -"Where do you want to be?"-is a question, the director reflected, you ask yourself as a storyteller:

What is it you're going to do in life? What are the stories that are in me and the best way to tell them? The stories must arise from who you are. My whole career spans over forty years of making movies and TV shows. And for me, all those are media to be explored, but the stories all originate in me.

During Q\&A, Treviño reacted to the representations of minority characters in TV crime drama, where the latter are often the subject of criminal investigation. Treviño has sometimes declined offers to direct because the story resorted to the stereotypical character of the Mexican American villain. He mentioned one occasion where Puerto Rican American actor Luis Guzmán ${ }^{10}$ had been asked to play a child pornographer and Treviño had argued with the producer over it. In the end, Guzmán himself turned it down, saying he had six children, and the producers ended up making the villain a rich white European kid.

The second question was on his book, Eyewitness: A Filmmaker's Memoir of the Chicano Movement (2001), where he had detailed his relationship with his father and with director Luis Valdez, ${ }^{11}$ famous for writing and directing La Bamba (USA, 1987). The book focuses mainly on the period 1966-1967, then fastforwards to the 2000s to assess where we stand today. Treviño said he hadn't wanted to be polemical and had stayed clear of 
his relationships with women and anything that wasn't essential to the Chicano movement.

21 The third question concerned the industry and whether it has evolved. Treviño answered that the simple fact that he has directed all these episodes testifies to some change. At one point, he had practically given up on filmmaking. In the 1970s, he couldn't even find an agent who wanted to take him on. After a period of roughly ten years where Treviño mostly taught in a university, he ended up being offered a job to direct an episode of CBS Schoolbreak Special (1984-1996) entitled "Gangs." What with the awards that followed and the changing times, he now had the talent agencies calling him up. He soon became the television industry's Latino director.

Finally, a student asked the director if he felt his liberal arts background had informed his life and work at all. Treviño stated that it had definitely exposed him to lots of ideas he wouldn't have had at Columbia or a technical school. For instance, he called on his art background when he directed the episode from NYPD Blue by recycling the weird creatures invented by the painter Jérôme Bosch to evoke the drug dementia in a night club scene. He had replicated giant art photos of moments from Bosch and called it The Garden of Earthly Delights.

\section{Jim Mendiola ${ }^{12}$}

Mary Beltrán introduced the last speaker in the series of conferences. This series has been an opportunity to showcase directors who have endeavored to produce exciting work in spite of the industry's continuing reluctance to explore Latina/Latino topics. All three directors are, in this respect, models. Beltrán was particularly happy to present Jim Mendiola whose award-winning short film "Pretty Vacant" (1996) had an important role in her life, because it had found resonance with her own hybrid identity. Born in 1963, a native of San Antonio, Mendiola's work depicts a hip Latino culture and conveys the sense of excitement and joy in their everyday lives. His films have been screened at South by Southwest and the Guggenheim Museum. He has also produced Ozzy Goes to the Alamo (2001), the first Latino 3D movie, with artist Ruben Ortiz Torres, and has worked as a curator for the Yerba Buena Center for the Arts in San Francisco. He is currently working on a documentary about the making of Viva Max (USA, Jerry Paris, 1969), a film that presented the battle of the Alamo from the point of view of Mexicans, in which the Daughters of Texas are the villains. Like his other work, it raises the question: Who gets to tell history?

Jim Mendiola was glad Don Howard ${ }^{13}$ was in the audience because the latter is one of his inspirations in making the Viva Max documentary. Mendiola was impressed by how Howard, in the documentary Letter from Waco (USA, 1997), took up the challenge of telling a story about a city of which people knew very little. Mendiola promised he would screen an excerpt from the rought cut of his one-hour-long film; he is scheduled to deliver the film this summer. Today he mainly wanted to talk about where he started in terms of narrative, and especially about his use of historical fact and truth in narrative fiction films. His approach is very close to that described in the recent Altermundos: Latin@ Speculative Literature, Film, and Popular Culture (2017), edited by Cathryn Josefina Merla-Watson and B.V. Olguin. Mendiola is interested in trying to maintain facts, while integrating them within a work of fiction. Most of the clips he showed are from fiction films, but all rely on historical facts and all deliberately blur 
the lines between fact and fiction, notably by taking the form of fake documentaries. Mendiola recalled that, at a screening at the University of Wisconsin-Madison, one viewer was very much upset at having been fooled into thinking that the movie was a fake.

The piece he is now working on started out as a traditional PBS-style documentary, with talking heads, interviews, archive footage and vérité footage of contemporary events he had witnessed. But the more he worked on it, the more he was tempted to abandon the pretense of an objective narrator. He finally decided to throw out the conventions of "being fair." The documentary will still be narrated in the third person, but with a point of view. He also decided to integrate his own obsession with The Alamo into the film. The documentary will be composed of three layers. The first deals with Viva Max, the 1969 movie Mendiola's film documents, made in San Antonio and based on the novel by Jim Lehrer. The author got the idea for the book when visiting San Antonio-he had been scolded by the Daughters of Texas for having the audacity to pee in The Alamo! He then got the idea of a fiction about a Mexican General who decides to conquer The Alamo today. A young producer, Mark Carliner, decided to make this political satire his first film. Although the city of San Antonio welcomed a movie shot on location, there was some unhappiness that The Alamo myth was to be treated with so little reverence. The Alamo myth and symbol are what Mendiola sees as the second layer of his documentary: it is to be an analytical exploration of what The Alamo means. Including to someone like singer/drummer Phil Collins, an Alamo fan who owns the largest private collection of Alamo paraphernalia and actually believes he is the reincarnation of one of the soldiers who died in the battle! The third layer is more personal: it has to do with why Jim Mendiola decided to tell the story from his point of view. Mendiola is a fourth generation Mexican American, whose mother was not allowed to swim in the white people's swimming pool the year she was valedictorian of her High School. Mendiola has always wanted to tell specific Tejano stories to mainstream audiences. The challenge for him is to tell meaningful and nuanced stories based on facts without boring the audience.

"Pretty Vacant" is the story of Molly, a young Latina who defies her family by refusing to go to Mexico for the summer because she wants to work on her zines. The Sex Pistols, who play a central role in the narrative as the title indicates, actually did perform in San Antonio in 1978. Mendola was very much aware of class differences when he made this film, as he was working as a waiter on the Riverwalk in downtown San Antonio, where many tourists seemed to see Latin Americans as a homogeneous group. The short film was shot with a handheld $16 \mathrm{~mm}$ camera. It was influenced by two films in particular: Luis Valdez's first film, a short entitled I Am Joaquin (Mexico/USA, 1969), and by Robert Frank and Alfred Leslie's Pull My Daisy (1959). "Pretty Vacant" led to other opportunities, including at Sundance.

His second movie, the feature Come and Take It Day (USA, 2001), is a mockumentary with a Rashomon-like structure, i.e., three different narrators, and a caper genre movie climax that doesn't end well. At its core is the historical figure of folk hero Gregorio Cortez Lira. It was his time first time working with real actors, but the film was made with very little means (PBS contributed some money), and the equipment reflects that (it was made with Hi-8 digital and edited on Final Cut Pro 1). The film wasn't broadcast on TV, notably because the script had too many bad words. 
His second feature, Speeder Kills (2003), was made for $\$ 50,000$. It tells the story of an artist who decides to make a documentary about a local rock band. Speeder Kills served to document a specific moment in the history of San Antonio and captures a certain vibe of the music scene of then. In it, he mixed footage he had shot without the film in mind, as well as pictures taken by friends in bars; the heterogeneity of the visuals contributes to the film's crazy style. There is, of course, an Alamo sequence or reference, as in all of Mendiola's films.

Mendiola then worked on web-based material, and this ultimately led to the Viva Max documentary. The 1969 film was a good way to look at Mexican American identities. The Alamo has often been treated as a sort of holy place, and yet Mexican Americans from San Antonio habitually experience shame and anger when visiting a monument where you are told that Mexicans are cowards and that the heroes were all white.

The Q\&A brought to the fore the challenges and advantages of dealing with regionally specific material. The discussion also addressed the problem of funding of, and support for, Latino media productions, notably in order to increase visibility and distribution. Members of the audience were also struck by how successfully Mendiola's films depict Latina protagonists, and by the various forms and genres Mendiola had worked in.

Mary Beltrán and Charles Ramírez Berg are planning on pursuing the series of screening events next year.

To be continued...

\section{NOTES}

1. http://rtf.utexas.edu/faculty/mary-beltr\%C3\%A1n

2. http://rtf.utexas.edu/faculty/charles-ramirez-berg

3. http://www.imdb.com/name/nm0873266/?ref_=nv_sr_1\#director

4. http://www.imdb.com/name/nm0165101/?ref_=nv_sr_1

5. http://www.imdb.com/name/nm0877587/?ref_=fn_al_nm_1

6. http://www.metroarts.com.au/artist/thomas-quirk/

7. http://www.youtube.com/watch?v=Qc4ahnZzVM4

8. http://www.imdb.com/name/nm0000335/?ref_=nv_sr_1

9. http://www.imdb.com/name/nm0872442/?ref_=nv_sr_1

10. http://www.imdb.com/name/nm0350079/?ref_=nv_sr_1

11. http://www.imdb.com/name/nm0883609/?ref_=nv_sr_1

12. http://www.imdb.com/name/nm1005904/?ref_=fn_al_nm_1

13. http://www.imdb.com/name/nm0397252/?ref_=fn_al_nm_3 
INDEX

Subjects: Film

Keywords: film, television, series, documentary, narrative, Mexican American, Latin American, LGBTQ, identity politics, race, industry

\section{AUTHORS}

DAVID ROCHE

mudrock@neuf.fr 